\title{
Ecophysiology in environmental impact assessment: implications of spatial differences in seasonal variability of bivalve condition
}

\author{
J. Norkko ${ }^{1,2,3, *}$, S. F. Thrush ${ }^{1}$ \\ ${ }^{1}$ National Institute of Water and Atmospheric Research, PO Box 11-115, Hamilton, New Zealand \\ ${ }^{2}$ School of Biological Sciences, The University of Auckland, Private Bag 92019, Auckland, New Zealand
}

${ }^{3}$ Present address: Finnish Institute of Marine Research, PO Box 2, 00561 Helsinki, Finland

\begin{abstract}
Nucleic acid ratios (RNA:DNA, RNA:protein or total RNA content) have been successfully used as indirect measures of short-term growth in a range of marine organisms. However, using biochemical and physiological indicators in environmental impact assessment requires changes to be evaluated against a background of natural variability (e.g. spatial differences in the seasonal variability and size-dependence in bivalve condition). The natural temporal and spatial variability in nucleic acid ratios and condition indices in adult cockles Austrovenus stutchburyi was investigated along a gradient of increasing sediment grain size and wave exposure in an estuary on the east coast of New Zealand. The results were examined in relation to bivalve reproductive state, water temperature, and sediment and hydrodynamic characteristics of the estuary. The magnitude of seasonal variability in RNA was site-specific and increased towards more exposed sites, likely due to enhanced food availability at these sites. In addition, investigation of the effect of bivalve size class on nucleic acid ratios and condition indices revealed site-specific patterns. Thus, by integrating information over a range of spatial and temporal scales, we can increase our understanding of the interaction between the physiology of estuarine soft-sediment bivalves and their spatially and temporally complex environment to provide a sound basis for assessing the effects of added environmental stressors.
\end{abstract}

KEY WORDS: Impact assessment $\cdot$ Nucleic acid ratios $\cdot$ RNA $\cdot$ Condition index $\cdot$ Natural variability Size class $\cdot$ Austrovenus stutchburyi

\section{INTRODUCTION}

Marine benthic communities function within the constraints of changing environmental conditions. To better understand the dynamics of this relationship, an increased understanding of physiological mechanisms that link environmental conditions to ecological responses is imperative (Niemi \& McDonald 2004). A further key issue in ecology and resource management is how to integrate processes that occur across different spatial and temporal scales, and different levels of biological organisation (Thrush et al. 1997, Niemi \& McDonald 2004). This is of particular importance in dynamic and heterogeneous habitats such as estuaries, which are characterised by steep gradients in physical and chemical properties that vary in both time and space.

Suspension-feeding bivalves are often key species in estuarine and coastal habitats (Dame 1993), and small changes in metabolic activity may over time lead to large changes in community structure through changes in growth and survival (Dahlhoff et al. 2002). Accordingly, the development of sensitive methods for assessing changes in bivalve populations is essential for a better understanding of the functioning and stress response in coastal marine ecosystems. For example, nu- 
cleic acid ratios (RNA:DNA, RNA:protein or total RNA content) are measures of protein synthesis potential that have been used as indirect measures of short-term growth rate in a range of marine organisms (Houlihan 1991, Buckley et al. 1999, Dahlhoff 2004). Both spatial and temporal variability in nucleic acid ratios have been recorded in field-collected and transplanted bivalves, and the variability has often been linked to changes in food availability (e.g. Dahlhoff \& Menge 1996, Menge et al. 1999, Norkko et al. 2005a,b). Thus, there is evidence for variability in nucleic acid ratios over a wide range of spatial and temporal scales, but few studies have investigated patterns in nucleic acid ratios both in time and in space. As the magnitude of natural temporal variability is predicted to vary among locations, such information is important and provides a sound basis for assessing the effects of added environmental stressors (Romero 2004).

Field studies that investigate both biochemical (nucleic acid ratios) and physiological (condition) indices in bivalves appear to be lacking, despite the extensive application of condition indices as a measure of bivalve nutritional status or recent physiological stress (Crosby \& Gale 1990). Nucleic acid ratios and condition indices are correlated to a certain extent. For example, Wright \& Hetzel (1985) found a moderate correlation ( $\mathrm{r}=0.396, \mathrm{p}<0.05, \mathrm{n}=86$ ) between a condition index and the RNA:DNA ratio of Crassostrea virginica mantle tissue in an 8 wk laboratory experiment. However, asymmetry in response times for these measures is likely, because nucleic acid ratios represent short-term metabolic activity whereas condition indices reflect longer-term changes in tissue accrual and shell growth.

Growth implies changes to metabolism through the mass-dependence of energy utilisation (SchmidtNielsen 1984). Thus, the higher growth rates of juveniles compared to adults should be reflected in higher nucleic acid ratios in smaller individuals, but patterns are not always consistent across species or tissue types (Mayrand et al. 1994). Thus, species and tissue-specific investigation of size-dependent patterns in nucleic acid ratios appears necessary.

Even though laboratory validation is a prerequisite for the estimation of growth rates and nutritional status using nucleic acid ratios in field-collected invertebrates and fish (Clemmesen 1994, Dahlhoff et al. 2002), laboratory studies do not account for natural variations in growth rates caused by seasonal or other fluctuations in the environment. Nevertheless, field-based nucleic acid studies that integrate a range of environmental factors co-occurring in time and space are rare. By investigating bivalve nucleic acid ratios and condition indices along a natural estuarine gradient, full advantage can be taken both of small-scale variability at the scale of the individual, and of larger scale variability at the scale of the estuary. This enables us to better identify how and why bivalve nucleic acid ratios and condition indices vary over different spatial and temporal scales in a natural context, and facilitates quantitative predictions for how bivalves may respond to stressors, for example elevated suspended sediment concentrations (SSC).

In this study, the natural temporal and spatial variability in nucleic acid ratios and condition indices in adult cockles Austrovenus stutchburyi was investigated. Monthly sampling was conducted along a gradient of increasing sediment grain size and wave exposure in a New Zealand estuary. Site-specific temporal variability, among spatial variability and estuary-wide variability in nucleic acid ratios and condition indices were examined in relation to bivalve reproductive state, water temperature, and sediment and hydrodynamic characteristics of the estuary. In addition, the site-specific effect of bivalve size class on nucleic acid ratios and condition indices was tested. Average values of nucleic acid ratios and condition indices, and the magnitude of their seasonal variability, were predicted to differ among sites in relation to environmental factors. However, as the 2 measures represent different levels of biological organisation, they were predicted to be affected differentially by environmental factors and to exhibit different temporal dynamics. By integrating information over a range of spatial and temporal scales, this study aimed to increase our understanding of the interaction between the physiology of estuarine soft-sediment bivalves and their spatially and temporally complex environment. Further, it aimed to evaluate the utility of including nucleic acid ratios as a complement to traditional condition indices in ecological field studies.

\section{MATERIALS AND METHODS}

Study species. The suspension-feeding cockle Austrovenus stutchburyi (Veneridae, hereafter Austrovenus) is often the dominant component of macrofaunal biomass on intertidal flats in New Zealand. Although Austrovenus are found in a wide range of habitats, including habitats with high mud content, maximum densities are found in sandy habitats (Thrush et al. 2003). Moreover, they are sensitive to highly elevated SSC as well as terrestrial sediment deposition events following heavy rain and flooding (Norkko et al. 2002, Lohrer et al. 2004). As Austrovenus occur in a wide range of habitats, the species is particularly appropriate for investigating how bivalve physiological responses change in relation to gradients in the environment. 
Study site and field methods. The study was conducted in the Okura estuary on the east coast of New Zealand $\left(36^{\circ} 40^{\prime} \mathrm{S}, 174^{\circ} 43^{\prime} \mathrm{E}\right.$; Fig. 1). The range of semidiurnal tides is about $2.5 \mathrm{~m}$ and there is no difference in salinity among the study sites, as water exchange in the estuary is virtually complete every tidal cycle (Oldman et al. 2002). Salinity in the estuary is around $30 \mathrm{ppt}$, except during major storm events when heavy flooding from the river may cause salinity to fall to as low as 7 ppt (M. Stewart pers. comm.). Okura is representative of many small, largely infilled estuaries, with small catchments and good tidal exchange.

Monthly sampling of Austrovenus was conducted for $2 \mathrm{yr}$, beginning in winter (July) 2000. Bivalves were collected at mid-tidal level from 6 sites situated along a gradient of increasing distance from the mouth of the estuary, encompassing a range of muddy to sandy habitats (Fig. 1). Austrovenus were most abundant at Sites 2, 5 and 6. Due to greater exposure to wind-wave disturbance, sediment grain size and sediment resuspension and transport are greatest near the mouth of the estuary, and both decrease towards the inner parts of the estuary (Oldman et al. 2002). Sediment chl a concentrations appear relatively constant over time and are similar among sites, except for very at muddy sites where higher concentrations may occur (Norkko et al. 2002).

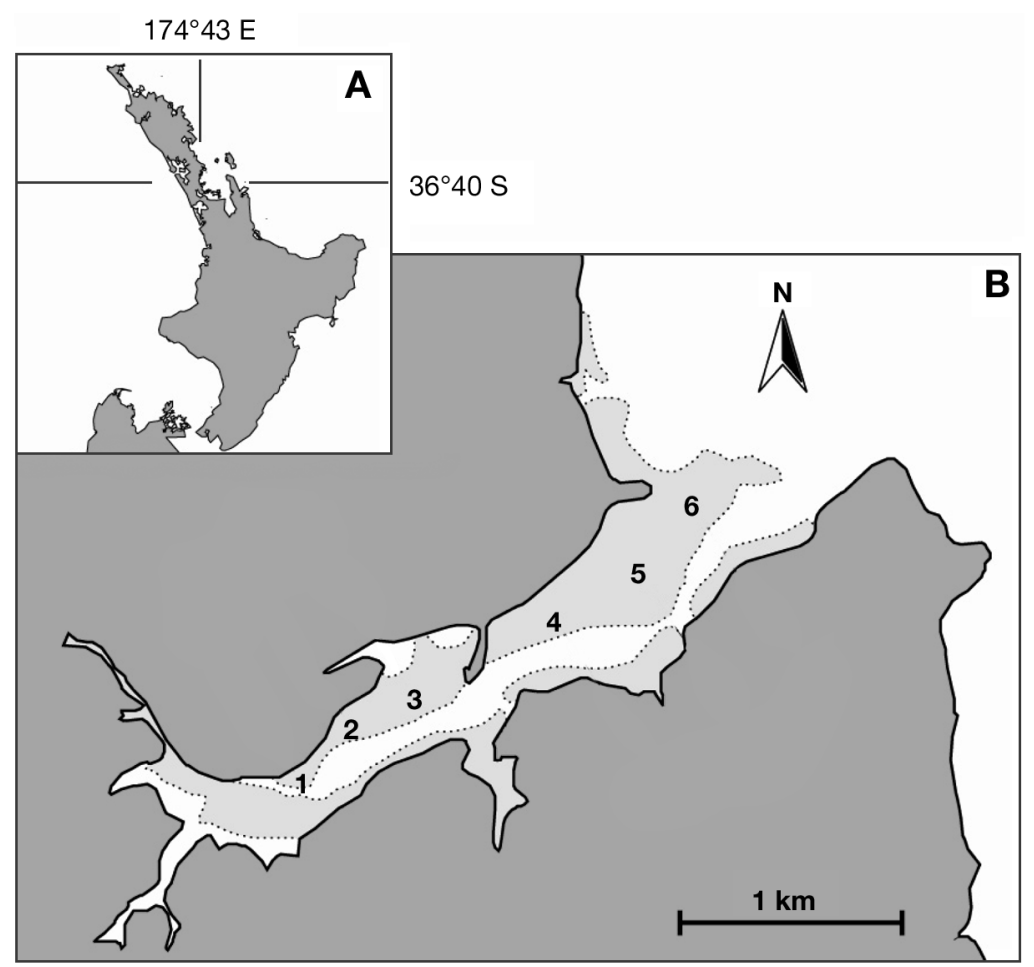

Fig. 1. (A) Location of Okura estuary in the North Island of New Zealand and (B) 6 study sites within the estuary. Shaded areas: intertidal sand and mudflats
Every month, 12 adult Austrovenus (20 to $25 \mathrm{~mm}$ ) were collected by hand along a $24 \mathrm{~m}$ transect line ( 1 ind. every $2 \mathrm{~m}$ ) laid parallel to the main tidal channel at each of the 6 sites. Sampling along the $24 \mathrm{~m}$ transect was carried out to minimise the possibility of smallscale variability in nucleic acid ratios caused by patchiness of the habitat (Mayrand et al. 1994). Sampling was always conducted at a low tide around noon, in order to avoid errors caused by potential diel or tidally driven variations in nucleic acid content of the bivalves.

To investigate the effect of size class on nucleic acid ratios and condition indices, Austrovenus of different shell lengths (12 to $37 \mathrm{~mm}$ ) were collected in June 2002 from the sites with the lowest and highest condition indices (Sites 2 and 6, respectively).

On each sampling occasion, sediment cores $(2 \mathrm{~cm}$ diameter, $2 \mathrm{~cm}$ deep) were obtained at $0,6,12,18$ and $24 \mathrm{~m}$ along each transect and analysed for organic content (calculated from weight loss after combustion at $400^{\circ} \mathrm{C}$ for $6 \mathrm{~h}$, after drying the samples to constant weight at $60^{\circ} \mathrm{C}$ ). Measurements of sediment shear strength and compaction were made in close proximity of each sediment core using a shear vane $(90 \mathrm{~mm}$ diameter base) and penetrometer (25 $\mathrm{mm}$ diameter base), respectively. To characterise the sampling sites, sediment grain size was analysed in June 2002 in the cores taken for organic content. Samples for grain size analysis were digested in $6 \%$ hydrogen peroxide for $48 \mathrm{~h}$ to remove organic matter, then wet sieved on a series of sieves $(63,250,500$ and $2000 \mu \mathrm{m})$, dried at $60^{\circ} \mathrm{C}$, and weighed. Local coastal surface water temperatures were obtained from the Leigh Marine Laboratory and were used to indicate seasonality.

Biochemical analyses. Austrovenus were kept damp and on ice during transportation to the laboratory. For analysis of RNA content, adductor muscles were excised under a microscope within $6 \mathrm{~h}$ of collection, frozen in liquid nitrogen, and stored at $-70^{\circ} \mathrm{C}$. To obtain sufficient material for the analyses, freeze-dried muscle tissue from 4 bivalves (sampled from positions $1-4,5-8$ or $9-12$ on the transect) was pooled, pulverised in a glass mortar, and 10 to $12 \mathrm{mg}$ of muscle tissue was used for quantification of RNA. Total RNA was extracted using TRI Reagent (Molecular Research Centre, \#TR118/200; Chomczynski 1993) and quantified spectrophotometrically. An additional ethanol wash was added to the manufacturer's protocol to ensure 
samples of satisfactory purity. At $260 \mathrm{~nm}, 1$ absorbance unit corresponds to $40 \mu \mathrm{g} \mathrm{ml}^{-1}$ pure RNA. Only total RNA content ( $\mu \mathrm{g} \mathrm{mg}^{-1}$ tissue dry weight) of the adductor muscle is presented here, but similar patterns were found in RNA:protein ratios ( $\mathrm{r}=0.866, \mathrm{p}<0.0001)$, as protein content varied little among sites and over time.

Condition indices and reproductive state. For determination of physiological condition of Austrovenus, the gravimetric index $\left(\mathrm{CI}_{\text {grav }}\right)$ recommended by Crosby \& Gale (1990) was used:

$$
\begin{aligned}
\mathrm{CI}_{\text {grav }}= & \text { flesh dry weight } \times 1000 \times(\text { whole live } \\
& \text { weight }- \text { shell dry weight })^{-1}
\end{aligned}
$$

Condition was measured on the same individuals used for biochemical analyses, and the weight of the excised muscle tissue was included in the calculation of flesh dry weight. The $\mathrm{CI}_{\text {grav }}$ index estimates the proportion of the available shell cavity capacity utilised by the bivalve's soft tissues, and thus reflects recent tissue accrual or loss. This condition index ('condition index' hereafter CI) was significantly correlated with the ratio of flesh dry weight to shell weight $\left(\mathrm{CI}_{\text {shelli }} \mathrm{r}=0.808\right.$, $\mathrm{p}<$ 0.0001). While the $\mathrm{CI}_{\text {shell }}$ index compares metabolism directed towards either shell growth or soft tissues, without accounting for possible variations in shell shape or thickness, the $\mathrm{CI}_{\text {grav }}$ index is decoupled from shell growth and shape. For example, when bivalve shells are heavily infested with boring polychaetes or other shell-eroding organisms, using dry tissue weight to shell weight as a CI leads to an overestimation of physiological condition. A coarse visual assessment of reproductive state was made for each bivalve (ripeness on a scale of 0 to 3 , where $0=$ gonad not ripe and $3=$ gonad fully ripe).

Data analysis. To investigate the relative importance of factors operating at different spatial and temporal scales, data was analysed on 3 different scales: sitespecific temporal variability, among-site spatial variability (utilising results from the entire study period) and estuary-wide variability (utilising results from all sites over the entire study period). Relationships between RNA content (hereafter RNA) and CI were explored through correlation (Pearson product moment correlation) and linear regression. Similar analyses were used to investigate the relationship between different sediment characteristics, and between RNA or CI and factors such as coastal water temperatures and bivalve reproductive state. Linear regression was used to describe the relationship between size class and $\mathrm{CI}$, while a power function provided a better fit for the relationship between size class and RNA.

To determine the most important variables accounting for site-specific temporal variability in RNA and CI, stepwise multiple regressions with backward selection were used. These analyses were performed on all data (not monthly means). Variables included as predictors in the site-specific regressions were shell length, coastal water temperature, and sediment organic content, compaction and shear strength. Water temperature with a 0,2 and 4 mo lag was investigated in the multiple regressions, to determine the strongest relationship between RNA and coastal water temperature. To determine the best predictors of variability in RNA and CI on an estuary-wide scale, the same predictors were used as for the site-specific analyses. In addition, \% medium sand, \% silt and clay, and average orbital velocity at the bed (measure of wave exposure) calculated from a hydrodynamic model for the Okura estuary (Oldman et al. 2002) were included for each site. To test differences in RNA, CI and sediment characteristics between sites, seasons, or years, ANOVA followed by Sheffe's multiple comparison tests was used. Prior to analysis, data were examined for homogeneity of variances (F-test) and normality (Kolmogorov-Smirnov), and rank-transformed where necessary.

\section{RESULTS}

\section{Environmental variables}

Throughout the study, Sites 1 and 2 were characterised by 20 and $10 \mathrm{~cm}$ deep mud, respectively, with abundant Helice crassa crab burrows, whereas Sites 3 to 6 were characterised by firm sand, with increasing occurrence of sand ripples towards the mouth of the estuary. All sites consisted mainly of fine to very fine sands, but the innermost sites also had increasing proportions of silt and clay (Table 1). Sediment organic content averaged over time varied among sites $\left(F_{5,137}=\right.$ 106.5, p < 0.0001) and was highest and most variable at the sheltered inner sites (Sites 1 and 2), intermediate at Site 3, and lowest at the sites more exposed to windwave disturbance (Sites 4, 5 and 6) (Fig. 2A). This corresponded well with the hydrodynamic model of Okura estuary, where mean tidal velocities and wavegenerated orbital velocities at the bed generally increase towards the mouth of the estuary (Oldman et al. 2002) (Table 1).

The environmental gradient within the estuary was further defined by sediment geotechnical properties. Sediment compaction averaged over time varied among sites $\left(F_{5,138}=51.3, \mathrm{p}<0.0001\right)$ and was lowest at Sites 1 and 2 (Fig. 2B). Sediment shear strength also varied $\left(F_{5,138}=13.6, \mathrm{p}<0.0001\right)$ and was higher at Sites 1 and 2 compared with Sites 5 and 6 , and also higher at Site 3 compared with Sites 4, 5 and 6 (Fig. 2C). Overall, sediment organic content was negatively correlated with sediment compaction $(\mathrm{r}=-0.642, \mathrm{p}<0.0001$, 
Table 1. Environmental characteristics of 6 sites. Sediment grain size (\% weight) sampled in June 2002. Mean tidal and bed orbital velocities were generated from hydrodynamic models of Okura estuary (Oldman et al. 2002). Sites 1 to 6 are listed in order of increasing exposure

\begin{tabular}{|cccccccc|}
\hline Site & $\begin{array}{c}\text { Silt and } \\
\text { clay } \\
(0-63 \mu \mathrm{m})\end{array}$ & $\begin{array}{c}\text { Fine to very } \\
\text { fine sand } \\
(63-250 \mu \mathrm{m})\end{array}$ & $\begin{array}{c}\text { Medium } \\
\text { sand } \\
(250-500 \mu \mathrm{m})\end{array}$ & $\begin{array}{c}\text { Coarse } \\
\text { sand } \\
(500-2000 \mu \mathrm{m})\end{array}$ & $\begin{array}{c}\text { Mean neap-tidal } \\
\text { velocity } \\
\left(\mathrm{m} \mathrm{s}^{-1}\right)\end{array}$ & $\begin{array}{c}\text { Mean } \\
\text { spring-tidal velocity } \\
\left(\mathrm{m} \mathrm{s}^{-1}\right)\end{array}$ & $\begin{array}{c}\text { Mean orbital } \\
\text { velocity } \\
\left(\mathrm{m} \mathrm{s}^{-1}\right)\end{array}$ \\
\hline 1 & 26.4 & 72.4 & 1.0 & 0.1 & 0.038 & 0.067 & 0.007 \\
2 & 24.4 & 74.8 & 0.7 & 0.1 & 0.025 & 0.046 & 0.019 \\
3 & 7.4 & 92.3 & 0.3 & 0.0 & 0.025 & 0.078 \\
4 & 1.5 & 96.4 & 1.7 & 0.3 & 0.044 & 0.111 & 0.061 \\
5 & 0.3 & 98.8 & 1.0 & 0.0 & 0.068 & 0.104 \\
6 & 0.5 & 91.4 & 7.6 & 0.5 & 0.080 & 0.052 \\
\hline
\end{tabular}
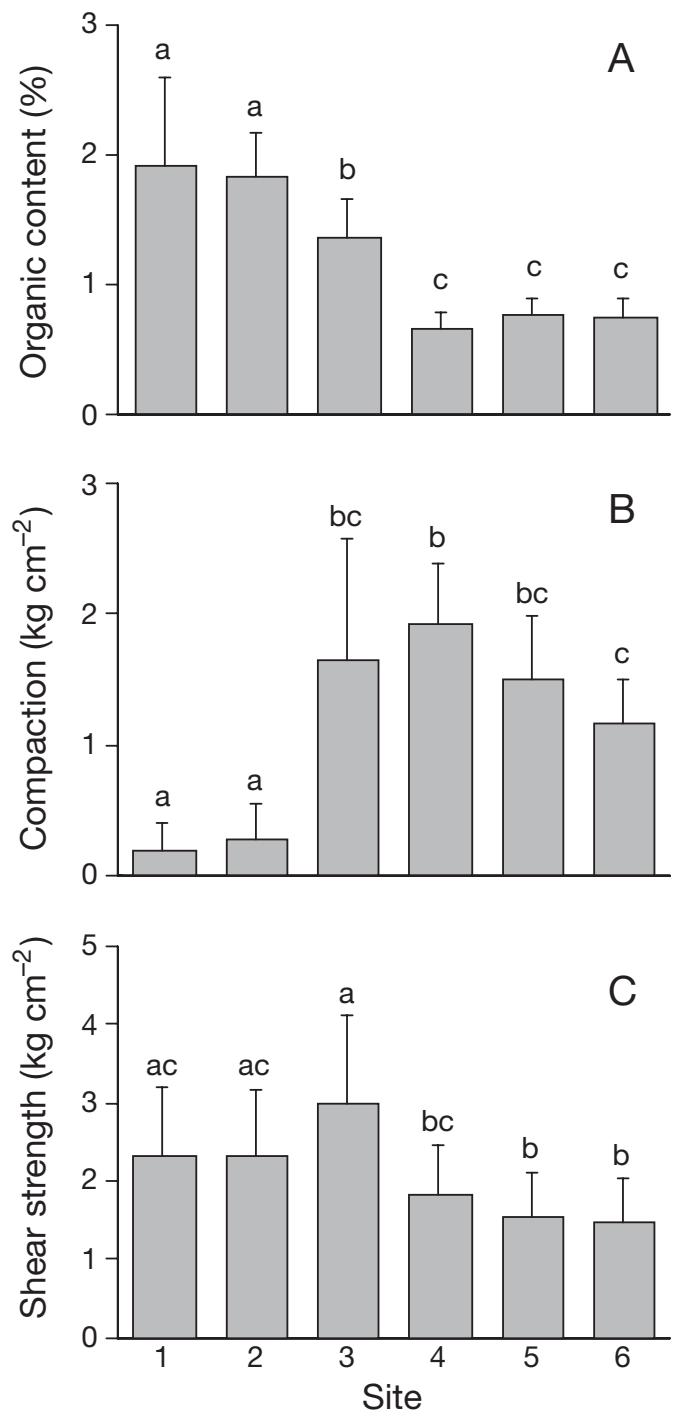

Fig. 2. Sediment characteristics at 6 sites averaged over time (mean $+\mathrm{SD}, \mathrm{n}=24)$. (A) Sediment organic content, (B) sediment compaction and (C) sediment shear strength. Sites denoted with different letters are significantly different from each other $(\mathrm{p} \leq 0.0085)$ (results of 1 -way ANOVA, organic: $F_{5,137}=106.5, \mathrm{p}<0.0001$; compaction: $F_{5,138}=51.3, \mathrm{p}<0.0001$; shear strength: $F_{5,138}=13.6, \mathrm{p}<0.0001$ ) $\mathrm{n}=143$ ) and weakly positively correlated with sediment shear strength $(\mathrm{r}=0.340, \mathrm{p}<0.0001, \mathrm{n}=143)$.

Coastal seawater temperatures varied seasonally between 14 and $21^{\circ} \mathrm{C}$. However, bivalves in the sediment are likely to experience much wider and more frequent fluctuations (between 5 and $30^{\circ} \mathrm{C}$ ) depending on weather conditions.

\section{Effect of Austrovenus size on RNA and CI}

For the monthly sampling, bivalves of uniform shell length were sampled in order to eliminate allometric bias (mean shell length $\pm \mathrm{SD}=21.7 \pm 2.0 \mathrm{~mm}$ ). However, a significant effect of size class on both RNA and CI was recorded when Austrovenus of a wider size range (12 to $37 \mathrm{~mm}$ ) were collected on one occasion from Sites 2 (muddy; lowest CI) and 6 (sandy; highest CI), but the relationship was site-specific (Fig. 3). RNA was more dependent on size class at the exposed site, as the smaller individuals at this site had markedly higher RNA, whereas the largest individuals at both sites had the same RNA (Fig. 3A). In contrast, CI was more related to size class at the muddy site, and decreased in larger individuals (Fig. 3B). At the exposed site, there was no significant relationship between CI and size $(p=0.2181)$.

\section{Spatial and temporal patterns in RNA and CI at different scales}

Considerable spatial and temporal variability was found in both RNA and CI in Austrovenus, with patterns changing along the estuarine gradient (Figs. 4, 5 \& 6). When site-specific results were averaged over time, adductor muscle RNA varied among sites $\left(F_{5,421}=17.0, \mathrm{p}<0.0001\right)$ and was significantly higher at Site 6 compared to all other sites (Fig. 4A). CI also differed among sites $\left(F_{5,426}=223.3, \mathrm{p}<0.0001\right)$, and increased successively from the innermost to the outermost sites (Fig. 4B). 

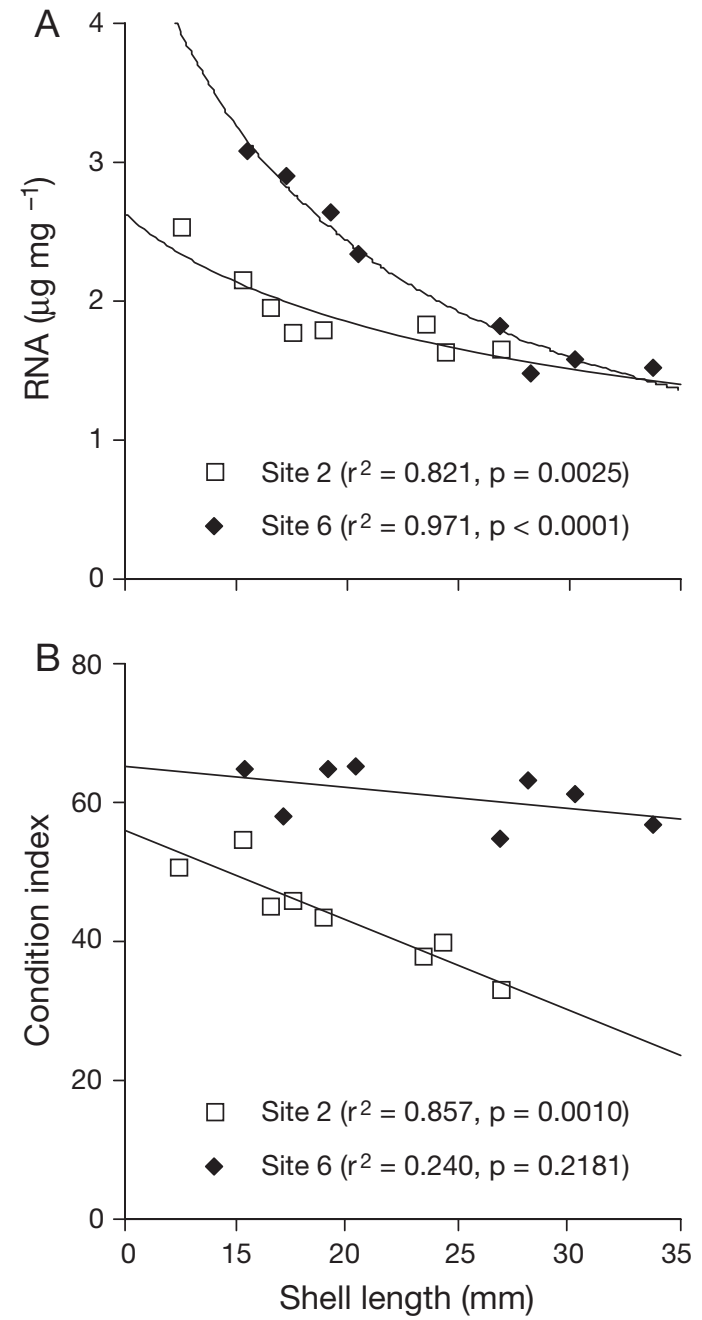

Fig. 3. Austrovenus stutchburyi. Relationship between size class and (A) RNA content (power function) and (B) condition index (linear function) at sites with lowest (Site 2) and highest (Site 6) condition indices

A seasonal cycle in both RNA and CI was recorded, but the pattern was site-specific and more pronounced at exposed sites compared to sheltered sites (Figs. 5 \& 6). The highest values of both parameters were normally observed in spring and early summer. Minimum RNA (monthly means) was similar among all sites. Maximum RNA was similar at Sites 1 to 5, but markedly higher at Site 6 . Conversely, both minimum and maximum values of $\mathrm{CI}$ increased towards the mouth of the estuary. The coefficients of variation (CV) from all samples collected over time at 1 site were higher for RNA ( 0.10 to 0.18 ) than CI ( 0.08 to 0.12$)$. However, at the estuary-wide scale, the $\mathrm{CV}$ was greater for $\mathrm{CI}(0.21)$, as it varied more among sites than RNA (0.16).

On the estuary-wide scale, a weak negative relationship was found between coastal seawater temperature and RNA (monthly means, all sites: $\mathrm{r}^{2}=0.049$, $\mathrm{p}=$
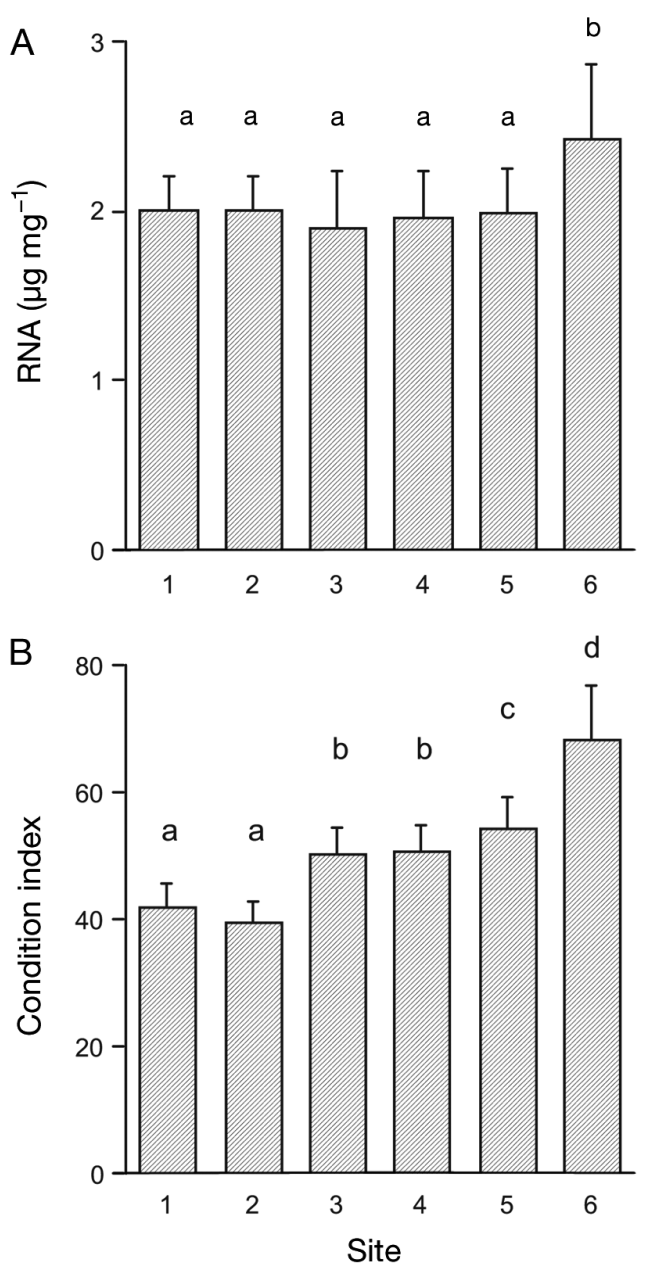

Fig. 4. Austrovenus stutchburyi. (A) RNA content of adductor muscle and (B) condition index at 6 sites averaged over time $($ mean $+\mathrm{SD}, \mathrm{n}=24)$. Sites denoted with different letters are significantly different from each other $(\mathrm{p} \leq 0.0012)$ (results of 1 -way ANOVA, RNA: $F_{5,421}=17.0, \mathrm{p}<0.0001$; condition: $\left.F_{5,426}=223.3, \mathrm{p}<0.0001\right)$

0.0077), but when lagging the RNA by 2 mo in relation to temperature this relationship was strengthened $\left(\mathrm{r}^{2}=\right.$ $0.228, p<0.0001)$. No such relationship was found between seawater temperature and CI (no lag: $\mathrm{r}^{2}=$ 0.008; 2 mo lag: $\mathrm{r}^{2}=0.032 ; 4$ mo lag: $\mathrm{r}^{2}=0.072$ )

When comparing site-specific interannual variation, RNA was markedly higher during the second year at Site 6, even though RNA at the other sites remained relatively similar (site $\times$ year interaction term: $F_{5,415}=$ 4.065, $\mathrm{p}=0.0013$; see Fig. 5, Site 6). No site-specific differences among years were observed for CI (site $\times$ year: $F_{5,420}=1.067, \mathrm{p}=0.3781$ ). Interannual differences in food availability appear the most likely explanation, but this remains to be tested.

On the estuary-wide scale, there was a moderate positive correlation between RNA and CI $(r=0.477$, $\mathrm{p}<0.0001)$. However, this relationship was site- 

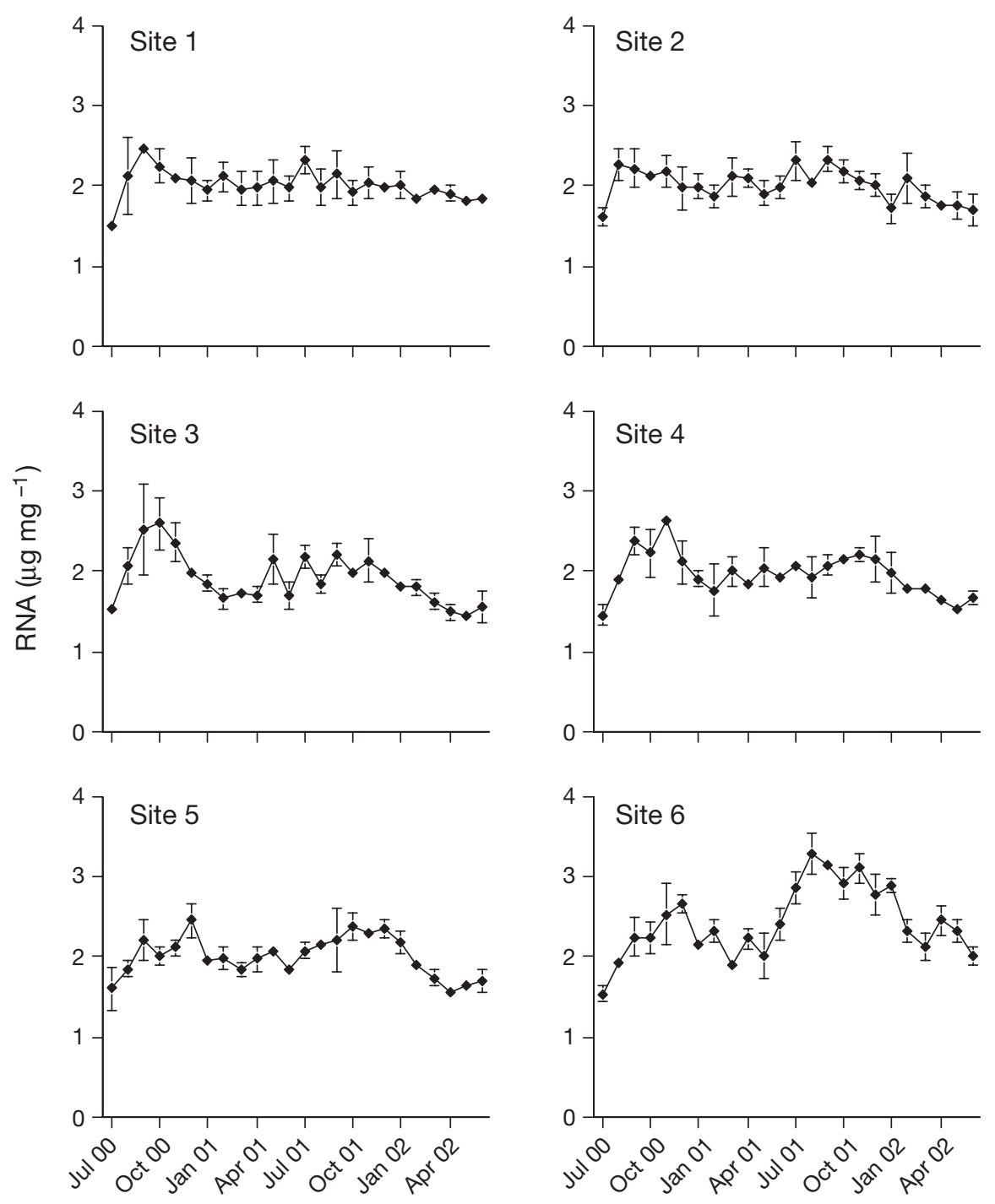

Fig. 5. Austrovenus stutchburyi. Site-specific temporal variability in RNA content of adductor muscle $(m e a n \pm S D, n=3)$

specific and the positive correlation between the 2 parameters strengthened towards the mouth of the estuary (Site 4: $r=0.283, p=0.0158$; Site 5: $r=0.380$, $\mathrm{p}=0.0010 ;$ Site 6: $\mathrm{r}=0.561, \mathrm{p}<0.0001$ ).

\section{Reproductive state}

No distinct seasonal pattern in reproductive state was observed, as ripe gonads were found at all times of the year in at least some individuals (Fig. 7). However, the least-developed gonads were generally observed in winter. Reproductive state averaged over time varied among sites $\left(F_{5,426}=14.458, \mathrm{p}<0.0001\right)$ and was lower at Site 1 compared to Sites 3,5 and 6 (p $\leq 0.0028)$, and lower at Site 2 compared to Sites 3, 4, 5 and 6 ( $\mathrm{p} \leq$ $0.0148)$. On the estuary-wide scale, no strong relation- ship was found between reproductive state and RNA $(r=0.152)$. However, a significant positive correlation was recorded at the estuary-wide scale between reproductive state and CI ( $\mathrm{r}=0.507, \mathrm{p}<0.0001)$ and, at all individual sites, CI averaged over time was positively correlated with reproductive state ( $\mathrm{r}=0.463$ to 0.555 , $\mathrm{p}<0.0001$, except at Site 4 where $\mathrm{r}=0.348, \mathrm{p}=0.0026$ ). In contrast, RNA was positively correlated with reproductive state only at Site $6(\mathrm{r}=0.517, \mathrm{p}<0.0001)$.

\section{Predicting variability in RNA and CI}

As both increasing RNA and increasing CI are signs of good health, similar environmental parameters could affect both measures, even though temporal scales of response may vary. Site-specific seasonal 

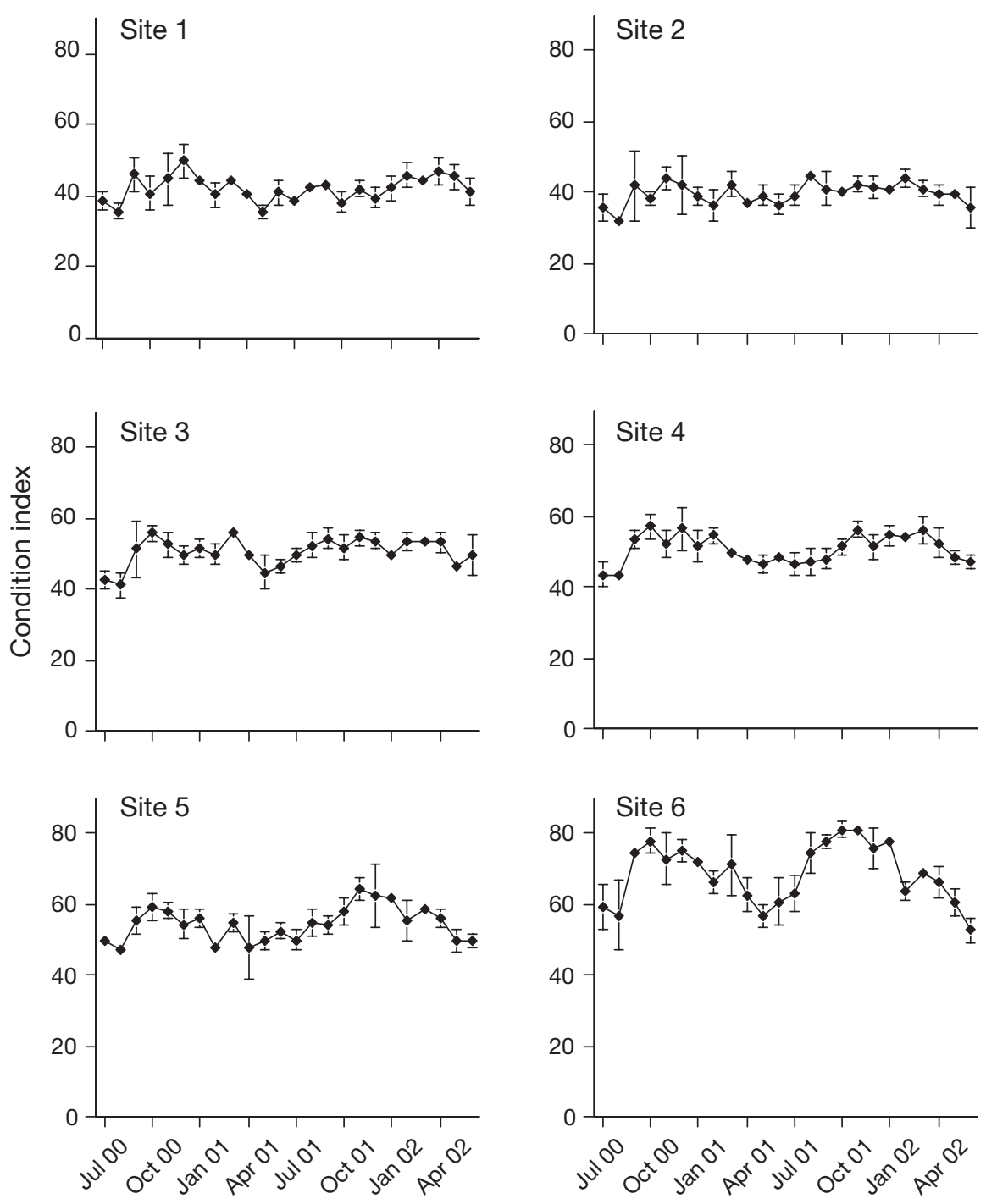

Fig. 6. Austrovenus stutchburyi. Site-specific temporal variability in condition index (mean $\pm \mathrm{SD}, \mathrm{n}=3$ )

Table 2. Best predictors of site-specific temporal variability in RNA. Size: shell length, Temp: coastal water temperature (2 mo lag), Org: sediment organic content, Shear: sediment shear strength, Comp: sediment compaction, (+) relationship positive, (-) relationship negative. Parameters listed in order of importance

\begin{tabular}{|cccc|}
\hline Site & $\mathrm{R}^{2}$ & $\mathrm{p}$ & Parameter \\
\hline 1 & 0.188 & 0.0003 & Shear (-) \\
2 & 0.267 & $<0.0001$ & Temp (-) \\
& & Org (-) \\
3 & 0.389 & $<0.0001$ & Temp (-) \\
4 & 0.351 & $<0.0001$ & Temp (-) \\
5 & 0.433 & $<0.0001$ & Temp (-) \\
& 0.668 & $<0.0001$ & Shear (+) \\
6 & & & Temp (-) \\
& & & Shear (+) \\
& & & Size (-) \\
& & & \\
\hline
\end{tabular}

variability in RNA was most notably related to coastal water temperatures, with the inclusion of sediment organic content, shear strength and compaction (Table 2). Site-specific variability in CI was also related to temperature, but the important factors differed more among sites than in the regression of RNA (Table 3). Sediment properties and bivalve shell length were also important. Generally, the amount of site-specific temporal variability accounted for by environmental variables increased towards the mouth of the estuary for both RNA and CI (Tables $2 \& 3$ ). The low explanatory power at the inner sites is accounted for by the low variability in RNA and CI at these sites (Figs. 5 \& 6).

Different environmental factors emerged as important predictors of variability in RNA and CI as the spatial scale was increased to encompass the whole estuary. Of the estuary-wide variability in RNA, 44.6\% 

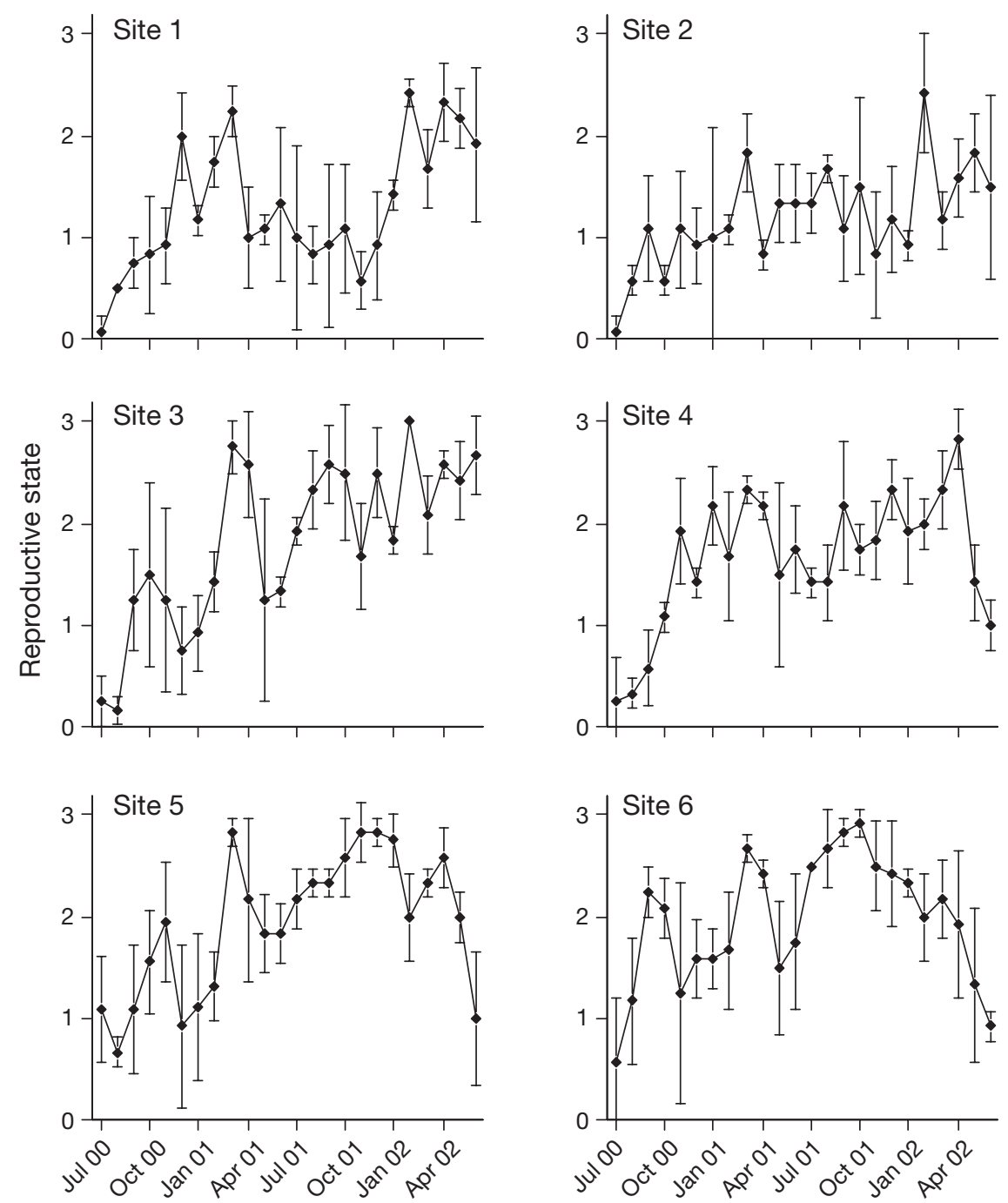

Fig. 7. Austrovenus stutchburyi. Site-specific temporal variability in index of reproductive state $(\mathrm{mean} \pm \mathrm{SD}, \mathrm{n}=3)$

Table 3. Best predictors of site-specific temporal variability in condition index. Parameters listed in order of importance. (+) relationship positive, (-) relationship negative. See Table 2 for abbreviations

\begin{tabular}{|c|c|c|c|}
\hline Site & $\mathrm{R}^{2}$ & $\mathrm{p}$ & Parameter \\
\hline 1 & 0.070 & 0.0277 & Size $(-)$ \\
\hline 2 & 0.184 & 0.0009 & $\begin{array}{r}\text { Size (-) } \\
\text { Temp (-) }\end{array}$ \\
\hline 3 & 0.314 & $<0.0001$ & $\begin{array}{l}\text { Shear }(+) \\
\text { Temp (-) }\end{array}$ \\
\hline 4 & 0.222 & 0.0002 & $\begin{array}{r}\text { Org (+) } \\
\text { Temp (-) }\end{array}$ \\
\hline 5 & 0.432 & $<0.0001$ & $\begin{array}{r}\text { Temp }(-) \\
\text { Comp (-) } \\
\text { Size (-) } \\
\text { Shear (+) }\end{array}$ \\
\hline 6 & 0.570 & $<0.0001$ & $\begin{array}{r}\text { Temp }(-) \\
\text { Comp (-) } \\
\text { Shear }(+) \\
\text { Org }(+)\end{array}$ \\
\hline
\end{tabular}

was explained by \% medium sand, coastal water temperature, sediment shear strength and compaction, and orbital velocity (Table 4). Correspondingly, 76.2\% of the estuary-wide variability in CI was explained by $\%$ medium sand, \% silt and clay, coastal water temperature, and sediment shear strength and compaction. In the estuary-wide analysis, shell length was not related to either RNA or CI (Table 4).

\section{DISCUSSION}

When using biochemical or physiological indicators to detect human impacts on marine environments, results need to be evaluated within a wider ecological context and against a background of natural variability in the response variable. Our results demonstrate spatial and temporal variability of nucleic acid ratios and 
Table 4. Best predictors of estuary-wide variability in RNA and condition index $(\mathrm{CI})$; med sand: medium sand $(250-500$ $\mu \mathrm{m})$, silt: silt and clay $(0-63 \mu \mathrm{m})$, Orb vel: orbital velocity. $(+)$ relationship positive, (-) relationship negative. See Table 2 for other abbreviations

\begin{tabular}{|c|c|c|c|}
\hline & $\mathrm{R}^{2}$ & $\mathrm{p}$ & Parameter \\
\hline RNA & 0.446 & $<0.0001$ & $\begin{array}{c}\text { \% med sand (+) } \\
\text { Temp }(-) \\
\text { Shear }(+) \\
\text { Comp }(-) \\
\text { Orb vel }(+)\end{array}$ \\
\hline CI & 0.760 & $<0.0001$ & $\begin{array}{c}\% \text { med sand }(+) \\
\% \text { silt }(-) \\
\text { Temp }(-) \\
\text { Shear }(+) \\
\text { Comp }(-)\end{array}$ \\
\hline
\end{tabular}

CI in Austrovenus. Although relationships between bivalve physiology and environmental factors could be partly explained by the estuarine gradient, the sites more exposed to wind-wave disturbance showed the largest temporal variability. By examining the results on several different scales and integrating over both time and space, a more general pattern emerges and it becomes apparent that specific environmental drivers may be linked to physiological responses. It is always necessary to balance the intensity of sampling with how well the sampling is representative of the environment. Here we focused on intensively sampling 1 estuary over time, and sampled a range of sites within the estuary, thus encompassing a range of environmental variables that influence the variables of interest. RNA was highest at the most exposed site, whereas all other sites had similar average RNA. On the other hand, CI increased gradually towards the mouth of the estuary. The low variability in RNA at the 2 most sheltered sites indicates suppressed metabolic activity throughout the year, i.e. environmental conditions are never favourable enough to maximise growth. Concordant with RNA and CI variation across Okura estuary, densities of Austrovenus exhibit a positive relationship with coarser sediment grain sizes and areas of lower sediment deposition (Anderson et al. 2004).

\section{Seasonality, reproductive cycles and temperature}

Seasonal patterns in bivalve condition indices typically include increases in condition before spawning, and are usually tightly coupled to the reproductive cycle (Newell \& Bayne 1980). Using histological staging and quantitative measures of oocytes, Stewart (2005) found that Austrovenus in Okura exhibited a prolonged spawning period with gametogenesis beginning around June and peak spawning occurring from November to March, which corresponds well with our visual assessment. Although CI was positively related to Austrovenus reproductive state at all sites, RNA was positively related to reproductive state only at Site 6, indicating that RNA is not as tightly coupled to reproductive state as CI. As RNA of adductor muscle was measured, the RNA does not directly reflect the metabolic activity of the gonad, which thus potentially accounts for the apparent uncoupling of RNA and reproductive state. Variations in RNA:DNA ratios of adductor muscle in the scallop Placopecten magellanicus were similarly not tightly bound to the reproductive cycle (Roddick et al. 1999). This uncoupling from reproductive state requires further investigation: studies of seasonal patterns in both muscle and/or gonad RNA and reproductive state are rare, but RNA may be a useful supplement to morphometric condition indices.

In Austrovenus, the highest CI and shell growth rates were observed in spring (Marsden \& Pilkington 1995, Stewart 2005). In the present study, highest RNA and CI were also recorded in spring, but the range of temporal variation in both parameters varied among sites, being greater at the more exposed sites. The multiple regression analyses showed that both RNA and CI were negatively related to coastal water temperatures, both at the scale of individual sites and across the estuary. The relationship with temperature may well reflect other thermally-dependent variables such as phytoplankton density. It has been suggested that increased temperatures may result in higher RNA turnover rather than higher RNA content (Buckley 1982), which explains why higher growth rates can be achieved with lower nucleic acid ratios at higher temperatures.

\section{Importance of food availability}

Patterns in bivalve nucleic acid ratios have commonly been linked to variability in food availability (Dahlhoff 2004, Norkko et al. 2006). Parameters measured in this study only explained $45 \%$ of the estuarywide variability in RNA, compared to $76 \%$ for $\mathrm{CI}$, indicating that additional factors such as food availability are likely to be important. Phytoplankton from the coastal area adjacent to the estuary may fuel production, but is likely to be depleted by bivalves at the estuary mouth before reaching the upper estuary, depending on depth and turbulence (Riisgaard et al. 2004). Suspension-feeding bivalves may also utilise microphytobenthos as a food source, but only after resuspension in the water column (Grant 1996). As resuspension is greatest at the estuary entrance, bivalves in 
this exposed area should benefit from increased food availability. A similar pattern was also observed in another New Zealand estuary, where both the amount and the organic content of settling material were highest at exposed sites and corresponded to high RNA and CI in the bivalves (Norkko et al. 2006). The low RNA and CI of Austrovenus at the innermost sites could thus be due to lower food availability and high $\mathrm{SSC}$, despite higher organic content in the sediment.

\section{Response dynamics of nucleic acid ratios and condition indices}

The lowest monthly RNA was independent of site and approached the same value in all individuals in the larger size classes, indicating a baseline for RNA. This may represent the base metabolism required for vital protein synthesis (Houlihan 1991; approximately $1.40 \mu \mathrm{g}$ RNA per mg tissue dry wt in this study), which is reached when the bivalve is almost fully grown. Under such conditions RNA-based indices are less likely to reveal responses to environmental factors. Interestingly, there does not seem to be an equivalent baseline for CI.

Several authors have reported higher nucleic acid ratios in smaller, faster growing bivalves (Lodeiros et al. 1996, Roddick et al. 1999). The relationship found between size class and RNA in the present study followed this pattern, but importantly, the shape of the relationship varied between sheltered and exposed sites. CI was more dependent on size class at the sheltered site, indicating that over time the condition of larger bivalves is compromised, possibly because of long-term physiological stress related to the sedimentary regime at the site. These unfavourable conditions could also explain the small differences in RNA found among different size classes of Austrovenus at this site. At exposed sites, where all individuals were in relatively good condition, RNA exhibited more variation among size classes, which indicates that bivalves at these sites were more able to utilise food resources. As the relationship between size class and RNA or CI changes among sites, the use of a single standardisation equation for size could lead to spurious conclusions (Packard \& Boardman 1988). Our results emphasize the importance of considering body mass and food supply in biochemically- or physiologicallybased monitoring programmes or in experimental manipulations, unless size class is explicitly incorporated into the study design and analysis.

There is a high degree of variability in metabolic activity within a population living in physically heterogeneous, intertidal habitats, and high variability in nucleic acid ratios has been linked to high growth rates in bivalves (Dahlhoff et al. 2002). This corresponds well with the wide range of RNA content observed at Site 6 (Fig. 5). Further, the same average amount of RNA can support variable CI (compare Site 1 and 2 with Site 3, 4 and 5; Fig. 4). Thus, it appears that small and short-term increases in RNA can be manifested as significant differences in CI over longer time scales, and we hypothesise that only temporary peaks of elevated RNA are needed to sustain high CI or high growth rates. This could partly explain the lack of correlation between nucleic acid ratios and growth rates in some studies, and highlights the importance of accurate temporal resolution of the sampling.

\section{Implications for environmental impact assessment}

Intertidal species are expected to be well adapted to the exigencies of the environmental fluctuations and show considerable physiological plasticity. However, physiological compensation in a stressful environment is costly and fitness is indeed reduced over time, as exemplified by lower $\mathrm{CI}$ and lower variability in RNA at muddy sites. Further, the magnitude of seasonal variability in RNA was site-specific, and increased towards the more exposed sites with higher food quantity. A metabolic baseline for RNA suggests that the magnitude of response will depend on the initial RNA content, potentially masking the effect of added stressors. The actual effects observed will thus be the result of a number of interacting factors and will depend on the context of the stressor(s) (Niemi \& McDonald 2004). As RNA and CI reflect different processes (metabolism vs. tissue accrual), an approach utilising both can be advantageous: RNA appears more sensitive to smaller-scale differences or temporal variability within sites, whereas $\mathrm{CI}$ is more suited to broader-scale comparisons. However, the size-, siteand time-specific patterns in RNA and CI clearly demonstrate the necessity of analysing biochemical and physiological data in a broader ecological context, to provide the basis for concluding whether an observed change is within the range of natural variation or is likely to be induced by the stressor of interest.

Acknowledgements. This research was funded by the New Zealand Foundation for Research, Science and Technology (COX0504, CO1X0307), and a National Institute of Water and Atmospheric Research (New Zealand) PhD scholarship and a stipend from Svenska Kulturfonden (Carl Cedercreutz Fund, Finland) to J. N. J. Hewitt provided advice on statistical analyses and R. Wells provided advice on methods for analysing nucleic acids. M. Thorndyke at Kristineberg Marine Research Station, Sweden, generously provided desk space during manuscript preparation. R. Wells, A. Norkko, C. Lundquist and 3 anonymous reviewers provided valuable comments on the manuscript. 


\section{LITERATURE CITED}

Anderson MJ, Ford RB, Feary DA, Honeywill C (2004) Quantitative measures of sedimentation in an estuarine system and its relationship with intertidal soft-sediment infauna. Mar Ecol Prog Ser 272:33-48

Buckley LJ (1982) Effects of temperature on growth and biochemical composition of larval winter flounder Pseudopleuronectes americanus. Mar Ecol Prog Ser 8:181-186

Buckley L, Caldarone E, Ong TL (1999) RNA-DNA ratio and other nucleic acid-based indicators for growth and condition of marine fishes. Hydrobiologia 401:265-277

Chomczynski P (1993) A reagent for the single-step simultaneous isolation of RNA, DNA and proteins from cell and tissue samples. Biotechniques 15:532-536

Clemmesen C (1994) The effect of food availability, age or size on the RNA/DNA ratio of individually measured herring larvae: laboratory calibration. Mar Biol 118:377-382

Crosby MP, Gale LD (1990) A review and evaluation of bivalve condition index methodologies with a suggested standard method. J Shellfish Res 9:233-237

Dahlhoff EP (2004) Biochemical indicators of stress and metabolism: applications for marine ecological studies. Annu Rev Physiol 66:183-207

Dahlhoff EP, Menge BA (1996) Influence of phytoplankton concentration and wave exposure on the ecophysiology of Mytilus californianus. Mar Ecol Prog Ser 144:97-107

Dahlhoff EP, Stillman JH, Menge BA (2002) Physiological community ecology: variation in metabolic activity of ecologically important rocky intertidal invertebrates along environmental gradients. Integr Comp Biol 42:862-871

Dame RF (1993) Bivalve filter feeders and coastal and estuarine ecosystem processes. Springer-Verlag, Heidelberg

Grant J (1996) The relationship of bioenergetics and the environment to the field growth of cultured bivalves. J Exp Mar Biol Ecol 200:239-256

Houlihan DF (1991) Protein turnover in ectotherms and its relationships to energetics. In: Gilles R (ed) Advances in comparative and environmental physiology, Vol 7 . Springer-Verlag, Heidelberg, p 1-43

Lodeiros CJM, Fernández RI, Bonmati A, Himmelman JH, Chung KS (1996) Relation of RNA/DNA ratios to growth for the scallop Euvola (Pecten) ziczac in suspended culture. Mar Biol 126:245-251

Lohrer AM, Thrush SF, Hewitt JE, Berkenbusch K, Ahrens M, Cummings VJ (2004) Terrestrially derived sediment: response of marine macrobenthic communities to thin terrigenous deposits. Mar Ecol Prog Ser 273:121-138

Marsden ID, Pilkington RM (1995) Spatial and temporal variations in the condition of Austrovenus stutchburyi Finlay, 1927 (Bivalvia: Veneridae) from the Avon-Heathcote estuary, Christchurch. NZ Nat Sci 22:57-67

Mayrand E, Pellerin-Massicotte J, Vincent B (1994) Small scale variability of biochemical indices of growth in Mya arenaria (L.). J Shellfish Res 13:199-205

Menge BA, Daley BA, Lubchenco J, Sanford E, Dahlhoff E, Halpin PM, Hudson G, Burnaford JL (1999) Top-down and

Editorial responsibility: Howard Browman (Associate Editorin-Chief), Storebø, Norway bottom-up regulation of New Zealand rocky intertidal communities. Ecol Monogr 69:297-330

Newell RIE, Bayne BL (1980) Seasonal changes in the physiology, reproductive condition and carbohydrate content of the cockle Cardium (= Cerastoderma) edule (Bivalvia: Cardiidae). Mar Biol 56:11-19

Niemi GJ, McDonald ME (2004) Application of ecological indicators. Annu Rev Ecol Evol Syst 35:89-111

Norkko A, Thrush SF, Hewitt JE, Cummings VJ and 5 others (2002) Smothering of estuarine sandflats by terrigenous clay: the role of wind-wave disturbance and bioturbation in site-dependent macrofaunal recovery. Mar Ecol Prog Ser 234:23-41

Norkko J, Norkko A, Thrush SF, Cummings VJ (2005a) Detecting growth under environmental extremes: spatial and temporal patterns in nucleic acid ratios in two Antarctic bivalves. J Exp Mar Biol Ecol 326:144-156

Norkko J, Pilditch CA, Thrush SF, Wells RMG (2005b) Effects of food availability and hypoxia on bivalves: the value of using multiple parameters to measure bivalve condition in environmental studies. Mar Ecol Prog Ser 298:205-218

Norkko J, Hewitt JE, Thrush SF (2006) Effects of increased sedimentation on the physiology of two esturarine softsediment bivalves, Austrovenus stutchburyi and Paphies australis. J Exp Mar Biol Ecol 333:12-26

Oldman J, Green M, Senior A (2002) Spatial variability of waves and relationship with bed sediments. Proc Int Conf Coast Eng 28:3078-3090

Packard GC, Boardman TJ (1988) The misuse of ratios, indices, and percentages in ecophysiological research. Physiol Zool 61:1-9

Riisgaard HU, Seerup DF, Jensen MH, Glob E, Larsen PS (2004) Grazing impact of filter-feeding zoobenthos in a Danish fjord. J Exp Mar Biol Ecol 307:261-271

Roddick D, Kenchington E, Grant J, Smith S (1999) Temporal variation in sea scallop (Placopecten magellanicus) adductor muscle RNA/DNA ratios in relation to gonosomatic cycles, off Digby, Nova Scotia. J Shellfish Res 18:405-413

Romero LM (2004) Physiological stress in ecology: lessons from biomedical research. Trends Ecol Evol 19:249-255

Schmidt-Nielsen K (1984) Scaling. Why is animal size so important? Cambridge University Press, Cambridge

Stewart MJ (2005) Ecological effects associated with urban development on populations of the New Zealand cockle (Austrovenus stutchburyi). PhD thesis, University of Auckland

Thrush SF, Schneider DC, Legendre P, Whitlatch RB and 9 others (1997) Scaling-up from experiments to complex ecological systems: where to next? J Exp Mar Biol Ecol 216:243-254

Thrush SF, Hewitt JE, Norkko A, Nicholls PE, Funnell GA, Ellis JI (2003) Habitat change in estuaries: predicting broad-scale responses of intertidal macrofauna to sediment mud content. Mar Ecol Prog Ser 263:101-112

Wright DA, Hetzel EW (1985) Use of RNA:DNA ratios as an indicator of nutritional stress in the American oyster Crassostrea virginica. Mar Ecol Prog Ser 25:199-206

Submitted: January 11, 2006; Accepted: April 20, 2006

Proofs received from author(s): November 11, 2006 